\title{
The epidemiology features of retroviral infections in domestic cats from the Zagreb urban area
}

\author{
Matko Perharić*, Vilim Starešina, Nenad Turk, Ljubo Barbić, \\ Zrinka Štritof, Suzana Hađina, Josipa Habuš, Vladimir Stevanović, \\ Krešimir Martinković, Vesna Mojčec Perko, and Zoran Milas \\ Department of Microbiology and Infectious Diseases with Clinic, Faculty of Veterinary Medicine, University \\ of Zagreb, Zagreb, Croatia
}

PERHARIĆ, M., V. STAREŠINA, N. TURK, LJ. BARBIĆ, Z. ŠTRITOF, S. HAĐINA, J. HABUS̆, V. STEVANOVIĆ, K. MARTINKOVIĆ, V. MOJČEC PERKO, Z. MILAS: The epidemiology features of retroviral infections in domestic cats from the Zagreb urban area. Vet. arhiv 88, 345-354, 2018.

\section{ABSTRACT}

Feline immunodeficiency virus (FIV) and feline leukaemia virus (FeLV) are among the most common infectious diseases of cats and have a global impact on the health of domestic cats. Both viruses belong to the Retroviridae family and like other members of this family they are associated with lifelong infection after integration of the proviral DNA into the host cell genome. Prevalence data are necessary to define the risk factors, and prophylactic, management, diagnostic and therapeutic measures for stray and owned sick cats. In this study 324 domestic cats were tested with commercially available assays. The tested cats were divided into two groups, stray and owned sick cats. The overall percentage of seropositives for FIV infection was $18.51 \%$ and the prevalence for FeLV infection was $14.50 \%$. FIV prevalence ranged from $13.13 \%$ in stray cats up to $20.88 \%$ within the sick owned cat group. The prevalence for FeLV infection was $6.06 \%$ in stray cats and $18.22 \%$ among sick owned cats. Regarding FIV infection, our study confirmed a significantly higher percentage of seropositives for male cats, as well as for sexually intact ones within the sick owned group. Males were significantly more likely to have positive results for both retroviral infections. The study confirmed the high rate of retroviral infections in cats from the Zagreb urban area. Males, sexually intact ones, and territorial aggression are predisposing factors for FIV infection, but not for FeLV. Preventive measures should include identification and segregation of infected cats, castration of outdoor male cats, and vaccination.

Key words: FIV; FeLV; prevalence; risk factors; prevention; Croatia

\footnotetext{
*Corresponding author:

Matko Perharić, PhD, Department of Microbiology and Infectious Diseases with Clinic, Faculty of Veterinary Medicine, University of Zagreb, Heinzelova 55, 10000 Zagreb, Croatia, Phone: +385 12390 211; E-mail: mperharic@vef.hr
} 
M. Perharić et al.: The epidemiology features of retroviral infections in domestic cats from the Zagreb urban area

\section{Introduction}

Feline immunodeficiency virus (FIV) and feline leukemia virus (FeLV) are retroviruses causing two of the most important and common infectious diseases of cats. Both viruses are enveloped RNA viruses. FIV belongs to the Lentivirus genus, while FeLV is classified in the genus Gammaretrovirus (HOSIE et al., 2009; LUTZ et al., 2009; HARTMANN, 2011). As both viruses possess reverse transcriptase for integration of the provirus into the host cell genome, FIV and FeLV cause lethal, untreatable and lifelong infections. Luckily, retroviruses survive a short period of time outside the host and both viruses are readily inactivated by a variety of disinfectants (PEDERSEN, 1993; SYKES, 2014). Domestic and wild cats are affected hosts (TROYER et al., 2005; MELI et al., 2009). The major mode of FIV transmission is through biting wounds and to a lesser extent transplacental, through colostrum, blood transfusion and possibly venereal routes (YAMAMOTO, 1989; PARK et al., 1995; ROGERS and HOOVER, 1998; JORDAN et al., 1999). Transmission of FeLV primarily results from close contact with salivary secretions, such as through mutual grooming, licking and shared food and water dishes. Viremic cats may also shed the infectious virus in multiple body fluids, including nasal secretions, faeces, milk and urine. Evidence of horizontal transmission of FeLV by cat fleas also exist (HARDY et al., 1976; PACITTI et al., 1986; VOBIS et al., 2003; GOMES-KELLER et al., 2009). Although infected cats may experience a prolonged period of time with no clinical abnormalities, a variety of clinical and disease conditions are associated with retroviral infections, including anaemia, hematological disorders, lymphoma, and chronic inflammatory conditions, as well as susceptibility to secondary and opportunistic infections. Specific disease syndromes are associated with a very high rate, such as cutaneous abscesses (FeLV 8.8\%, FIV 12.7\%) and oral inflammation (FeLV 7.3\%, FIV 7.9\%) (BELLOWS and LACHTARA, 2006; GOLDKAMP et al., 2008; LEVY et al., 2008). Due to the nonspecific and various clinical manifestation as well as the possibly long asymptomatic stage of FIV and FeLV infection, every sick cat and those with unknown retroviral status should be tested (LEVY et al., 2008; LITTLE et al., 2011). Nowadays, plenty of different commercially assays are used, either enzyme-linked immunosorbent assay (ELISA) or based on an immunochromatographic principle, to reveal retroviral infection. Beside the commercially available assays, various polymerase chain reaction (PCR), Western immunoblotting, virus isolation and immunofluorescent antibody (IFA) assays, performed by experienced laboratories are used to detect retroviral status (LITTLE et al., 2011).

FIV and FeLV infections are endemic in the domestic cat population worldwide. The prevalence of FeLV infection has reportedly decreased over the past two decades, probably as a result of widespread testing programs, the development of commercially available diagnostic assays, and due to the implementation of effective vaccines $\left(\mathrm{O}^{\prime} \mathrm{CONNOR}\right.$ et 
al., 1991; MOORE et al., 2004; LEVY et al., 2006; STUTZER et al., 2011). On the other hand, the prevalence of FIV infection has not altered since the virus was discovered in 1986 (PEDERSEN et al., 1987). The vaccine against FIV was not introduced until 2002 and its efficiency is still under debate, while the heterogeneity of the gene sequences poses a great problem for developing a broadly affective and protective vaccine again different subtypes of FIV (ELYAR et al., 1997; LEVY et al., 2008; COLEMAN et al., 2014). Retroviral seroprevalence is highly variable in different geographical areas as well as in different domestic cat categories.

Estimated FIV prevalences vary from 1 to $14 \%$ in cats with no clinical signs, up to $44 \%$ in sick cats (HARTMANN, 1998). More precisely, the data indicate that the seroprevalence of FIV in Italy ranged between $24-30.9 \%$ in the sick cat population (BANDECCHI et al., 1992; PENNISI and BO, 1994), while 10.7-14.1\% of clinically healthy cats were positive for FIV antibodies (PENNISI and BO, 1994; MAGI et al., 2002). Prevalence data obtained in Spain for FIV infection showed similar results, where $8.3 \%$ of healthy and $13.9 \%$ of clinically ill cats were positive (ARJONA et al., 2000). Other studies performed in Europe showed 27\% FIV infected cats in Serbia (POTKONJAK et al., 2014), 33.3\% in Slovenia (TOZON et al., 2008), 10.4\% in England (MUIRDEN, 2002), and from 3.2\% up to $8.4 \%$ in Germany (FUCHS et al., 1994; GLEICH et al., 2009). In Croatia, FIV was previously serologically confirmed in $3.3 \%$ of healthy and $10.3 \%$ of sick cats (KUČER et al., 2000).

For FeLV infection, the currently overall prevalence in the mixed cat population ranges from 1-6\% (LEVY et al., 2006; GLEICH et al., 2009; LITTLE et al., 2009; HELLARD et al., 2011). A prevalence study for FeLV infection in Slovenia found 23.8\% positive cats (TOZON et al., 2008), and a previous paper in Croatia showed $11.5 \%$ healthy and up to $14.9 \%$ clinically ill, positive cats (KUČER et al., 2000).

While FIV and FeLV can be life threatening viruses, proper management and treatment can give infected cats longer and healthier lives. The following study defines the current prevalence of FIV and FeLV in the Zagreb urban area, as well as determining predisposing factors and preventive measures for retroviral infections.

\section{Materials and methods}

The research was performed on 324 domestic cats presented to the Department of Microbiology and Infectious Disease with Clinic at the Faculty of Veterinary Medicine, University of Zagreb. The tested cats were divided into two groups, stray $(\mathrm{n}=99)$ and owned sick cats $(n=225)$. All stray cats have to be tested for retroviral infections prior to admittance to rescue shelters and afterwards to adoption programs. The majority of stray cats had no clinical abnormalities. Owned cats presented to the Clinic had health conditions which could be related to FIV and FeLV infection, so besides clinical treatment 
all these cats were tested. Within the owned sick cat group there were 125 males $(\mathrm{n}=$ 32 castrated males; $\mathrm{n}=93$ sexually intact males) and 100 female tested cats. All tested cats included in this study were older than 6 months, therefore maternal antibodies (stemming from an infection or vaccination of the mother) could not interfere with true retroviral status. Peripheral blood samples were obtained from v. cephalica antebrachi or v. jugularis into EDTA-coated tubes by an aseptic method. To confirm retroviral infection, commercially available assays $\left(\right.$ FASTest $^{\circledR}$ FIV; FASTest ${ }^{\circledR}$ FeLV, MEGACOR Diagnostic $\mathrm{GmbH}$, Austria) were used to evaluate 324 blood samples. FASTest ${ }^{\circledR}$ FIV is a rapid immunochromatographic test for the qualitative detection of FIV antibodies in whole blood, plasma or serum of cats. Also FASTest ${ }^{\circledR}$ FeLV is a rapid immunochromatographic test for the qualitative detection of FeLV group specific antigens (p27) in the whole blood, plasma or serum of cats. The reported sensitivity and specificity for FASTest ${ }^{\circledR}$ FIV were 96.4\% and 99.2\%, and for FASTest ${ }^{\circledR}$ FeLV 94.7\% and 98.8\% (HARTMANN et al., 2007). Diagnostic tests were performed immediately after blood sampling according to the manufacturer's instructions. All data were summarized using percentages, while for statistical comparison and analysis the $\chi 2$ test was used. A values of $\mathrm{P}<0.01, \mathrm{P}<0.05$ and $\mathrm{P}<0.10$ were considered significant. Due to inconsistent data for stray cats regarding sex, neutered status and age, only 225 owned sick cats were used for statistical analyses to evaluate risk factors.

\section{Results}

The overall $(n=324)$ percentage of seropositives seroprevalence for FIV was $18.51 \%(\mathrm{n}=60)$, and for FeLV $14.50 \%(\mathrm{n}=47)$. The percentage of seropositives for FIV infection ranged from $13.13 \%(n=13)$ in stray cats up to $20.88 \%(n=47)$ in the owned sick cat population. On the other hand, the prevalence for FeLV infection was $6.06 \%(n=6)$ in stray cats and $18.22 \%(n=41)$ in owned sick cats. The percentage of seropositives for FIV infection was significantly $(\mathrm{P}<0.01)$ higher in males $(31.20 \%$; $\mathrm{n}=$ $39)$ than in females $(8.00 \% ; n=8)$ in the owned sick cats' group. Furthermore, we found a significant difference $(\mathrm{P}<0.10)$ in FIV infection between sexually intact $(35.48 \% ; \mathrm{n}=33)$ and neutered males $(18.75 \% ; \mathrm{n}=6)$ within the group of owned sick cats. The prevalence of FeLV infection in males $(19.20 \% ; n=24)$ and females $(17.00 \% ; n=17)$ was not significantly different $(\mathrm{P}=0.67)$ amongst the owned sick cats. In our study we did not find any significant difference $(\mathrm{P}=0.26)$ in FeLV infection between neutered $(12.50 \%$; $\mathrm{n}=4)$ and sexually intact $(21.50 \% ; \mathrm{n}=20)$ males amongst the owned sick cats. Among the 225 tested owned sick cats $4.88 \%(n=11)$ were positive for both retroviral infections. Males $(8.00 \% ; n=10)$ were significantly $(\mathrm{P}<0.05)$ more likely to have positive results for both retroviral infections. The average ages of the owned sick cats were 7.9 years for FIV infected males and 6.1 years for females, while the average age for FeLV infection for both sexes was 4.3 years. 
M. Perharić et al.: The epidemiology features of retroviral infections in domestic cats from the Zagreb urban area

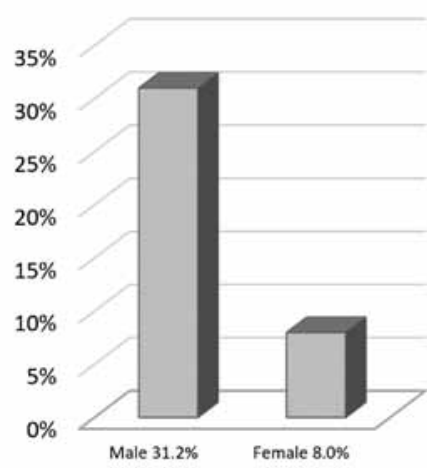

Fig. 1. Significantly higher seroprevalence in males for FIV infection

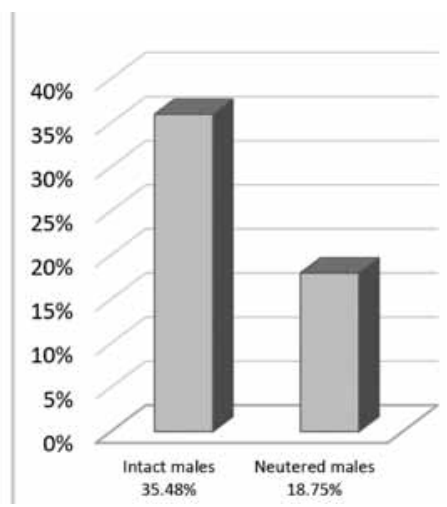

Fig. 2. Significantly higher seroprevalence in sexually intact males for FIV infection

Table 1. Prevalence of FIV and FeLV in the tested owned sick cats' group

\begin{tabular}{|l|c|c|}
\hline & \multicolumn{2}{|c|}{ Prevalence } \\
\hline Categories & FIV & FeLV \\
\hline Sexualy intact males & $33 / 93(35.48 \%)^{\mathrm{a}}$ & $20 / 93(21.50 \%)$ \\
\hline Neutered males & $6 / 32(18.75 \%)^{\mathrm{a}}$ & $4 / 32(12.50 \%)$ \\
\hline Total males & $39 / 125(31.20 \%)^{\mathrm{b}}$ & $24 / 125(19.20 \%)$ \\
\hline Total females & $8 / 100(8.00 \%)^{\mathrm{b}}$ & $17 / 100(17.00 \%)$ \\
\hline Total & $47 / 225(20.88 \%)$ & $41 / 225(18.22 \%)$ \\
\hline
\end{tabular}

${ }^{a}$ Significantly higher percentage of seropositives in sexually intact males in comparison with neutered males $(\mathrm{P}<0.10) ;{ }^{\text {b }}$ Significantly higher percentage of seropositives in males than in females $(\mathrm{P}<0.01)$

\section{Discussion and conclusions}

Feline immunodeficiency virus and feline leukaemia virus have worldwide distribution among domestic cats. Both viruses can remarkably alter the cat's life. Due to the relatively long incubation period, the diversity of clinical manifestations and possible extended asymptomatic stage of the infection, FIV and FeLV are often left undiagnosed. Lately owner awareness about retroviral infections is increasing, but there are still reasons for poor compliance among veterinarians and cat owners, possibly due to their incomplete understanding of the lifelong nature of retrovirus infection, insufficient communication skills, the inconvenience of physical re-evaluation of cats, and finally the cost of testing (LITTLE et al., 2011). For these reasons every sick cat and those with unknown retroviral status should be tested. 
Our study confirmed a high rate of retroviral infections in cats from the Zagreb urban area. The high FIV and FeLV prevalence is mainly a repercussion of the high density cat population in the urban area, the negligible number of vaccinated cats, the large number of stray cats, and generally infrequent testing.

This paper stresses the risk factors for FIV infection, which include male gender and outdoor access. Biting and territorial aggression are highly efficient modes for FIV transmission. Therefore, the natural territorial fighting behaviours of sexually intact male cats predispose them to a higher rate of FIV infection, which is confirmed in this research. This correlation between male sex and higher seroprevalence for FIV infection has been confirmed by several studies (ISHIDA et al., 1989; PERI et al., 1994; LEVY et al., 2006). The major mode for FeLV transmission is through saliva, milk, blood and urine, both vertically and horizontally. The difference between males and females regarding FeLV infection is usually not as large as for FIV (LEE et al., 2002). In our study, we did not find any significant difference for FeLV infection according to gender.

While testing and identification of infected cats are key tools for retroviral prevention of transmission, vaccination also play an important role. The combined use of testing and vaccination programs is assumed to have reduced the prevalence of FeLV infection over the past 20 years (O'CONNOR et al., 1991; MOORE et al., 2004; LEVY et al., 2006; LITTLE et al., 2011). Recommendations for use of the available FeLV vaccines have been published (RICHARDS et al., 2006; LEVY et al., 2008). Recommendations for FIV vaccines have also been published (RICHARDS et al., 2006; LEVY et al., 2008) but their efficiency is still under debate. Another important step for retroviral prevention is castration of all male cats that have outdoor access.

Further, more detailed research of retroviral prevalence and phylogenetic characterisation of viral strains are essential for developing better diagnostic tools, as well as highly effective prophylactic protocols.

\section{References}

ARJONA, A., E. ESCOLAR, I. SOTO, N. BAQUERO, D. MARTIN, E. GOMEZ-LUCIA (2000):

Seroepidemiological survey of infection by feline leukemia virus and immunodeficiency virus in Madrid and correlation with some clinical aspect. J. Clin. Microbiol. 38, 3448-3449.

BANDECCHI, P., D. MATTEUCCI, F. BALDINOTTI, G. GUIDI, F. ABRAMO, F. TOZZINI, M. BENDINELLI (1992): Prevalence of feline immunodeficiency virus and other retroviral infections in sick cats in Italy. Vet. Immunol. Immunolpathol. 31, 337-345.

BELLOWS, J., J. L. LACHTARA (2006): Feline Retroviruses and Oral Disease. Unpublished. Reported in Veterinary Medicine, Spot light on Research. 
M. Perharić et al.: The epidemiology features of retroviral infections in domestic cats from the Zagreb urban area

COLEMAN, J. K., R. PU, M. M. MARTIN, E. N. NOON-SONG, R. ZWIJNENBERG, J. K. YAMAMOTO (2014): Feline immunodeficiency virus (FIV) vaccine efficacy and FIV neutralizing antibodies. Vaccine. 32, 746-754.

ELYAR, J. S., M. C. TELLIER, J. M. SOOS, J. K. YAMAMOTO (1997): Perspectives on FIV vaccine development. Vaccine. 15, 1437-1444.

FUCHS, A., L. BINZEL, M. LONSDORFER (1994): Epidemiology of FeLV and FIV infection in the Federal Republic of Germany. Tierärztl. Praxis. 22, 271-277.

GLEICH, S. E., S. KRIEGER, K. HARTMANN (2009): Prevalence of feline immunodeficiency virus and feline leukemia virus among client-owned cats and risk factors for infection in Germany. J. Feline Med. Surg. 11, 985-992.

GOLDKAMP, C. E., J. K. LEVY, G. H. EDINBORO, J. L. LACHTARA (2008): Seroprevalences of feline leukemia virus and feline immunodeficiency virus in cats with abscesses or bite wounds and rate of veterinarian compliance with current guidelines for retrovirus testing. J. Am. Vet. Med. Assoc. 232, 1152-1158.

GOMES-KELLER, M. A., E. GÖNCZI, B. GRENACHER, R. TANDON, R. HOFMANNLEHMANN, H. LUTZ (2009): Fecal shedding of infectious feline leukemia virus and its nucleic acids: a transmission potential. Vet. Microbiol. 134, 208-217.

HARDY, W. D., A. J. McClELlAND, E. E. ZUCKERMANN, P. W. HESS, M. ESSEX, S. M. COTTER, E. G. MacEWEN, A. A. HAYES (1976): Prevention of the contagious spread of feline leukaemia virus and the development of leukaemia in pet cats. Nature 263, 326-328.

HARTMANN, K. (1998): Feline immunodeficiency virus inection: an overview. Vet. J. 155, 123137.

HARTMANN, K. (2011): Clinical aspects of feline immunodeficiency and feline leukemia virus infection. Vet. Immunol. Immunopathol. 143, 190-201.

HARTMANN, K., P. GRIESSMAYR, B. SCHULZ, C. E. GREENE, A. N. VIDYASHANKAR, O. JARRETT, H. F. EGBERNIK (2007): Quality of different in-clinic test systems for feline immunodeficiency virus and feline leukaemia virus infection. J. Feline Med. Surg. 9, 439-445.

HELlARD, E., D. FOUCHET, H. SANTIN-JANIN, B. TARIN, V. BADOL, C. COUPIER, G. LEBLANC, H. POULET, D. PONTIER (2011): When cats' ways of life interact with their viruses: a study in 15 natural populations of owned and unowned cats (Felis silvestris catus). Prev. Vet. Med. 101, 250-264.

HOSIE, M. J., D. ADDIE, S. BELAK, C. BOUCRAUT, H. F. EGBERNIK, T. FRYMUS, T. J. GRUFFYDD-JONES, K. HARTMANN, A. LLORET, H. LUTZ, F. MARSILIO, M. G. PENNISI, A. D. RADFORD, E. THIRY, U. TRUYEN, M. HORZINEK (2009): Feline immunodeficiency. ABCD guidelines on prevention and management. J. Feline Med. Surg. $11,575-584$.

ISHIDA, T., T. WASHIZU, K. TORIYABE, S. MOTOYOSHI, I. TOMODA, N. C. PEDERSEN (1989): Feline immunodeficiency virus infection in cats of Japan. J. Am. Vet. Med. Assoc. 194, 221-225.

Vet. arhiv 88 (3), 345-354, 2018 
M. Perharić et al.: The epidemiology features of retroviral infections in domestic cats from the Zagreb urban area

JORDAN, H. L., Y. LIANG, L. C. HUDSON, W. A. TOMPKINS (1999): Shedding of feline immunodeficiency virus in semen of domestic cats during acute infection. Am. J. Vet. Res. 60, 211-215.

KUČER, N., J. MADIĆ, LJ. BEDRICA (2000): Prevalence of antibodies of FIV and FeLV in Croatia. Praxis Vet. 3, 173-177.

LEE, I. T., J. K. LEVY, S. P. GORMAN, P. C. CRAWFORD, M. R. SLATER (2002): Prevalence of feline leukemia virus infection and serum antibodies against feline immunodeficiency virus in unowned free-roaming cats. J. Am. Vet. Med. Assoc. 220, 620-622.

LEVY, J., C. CRAWFORD, K. HARTMANN, R. HOFMANN-LEHMANN, S. LITTLE, E. SUNDAHL, V. THAYER (2008): 2008 American Association of Feline Practitioners' feline retrovirus management guidelines. J. Feline Med. Surg. 10, 300-316.

LEVY, J. K., H. M. SCOTT, J. L. LACHTARA, P. C. CRAWFORD (2006): Seroprevalence of feline leukemia virus and feline immunodeficiency virus infection among cats in North America and risk factors for seropositivity. J. Am. Vet. Med. Assoc. 228, 371-376.

LITTLE, S., D. BIENZLE, L. CARIOTO, H. CHISHOLM, E. O'BRIEN, M. SCHERK (2011): Feline leukemia virus and feline immunodeficiency virus in Canada: Recommendations for testing and management. Can. Vet. J. 52, 849-855.

LITTLE, S., W. SEARS, J. LACHTARA, D. BIENZLE (2009): Seroprevalence of feline leukemia virus and feline immunodeficiency virus infection among cats in Canada. Can. Vet. J. 50, 644648.

LUTZ, H., D. ADDIE, S. BELAK, C. BOUCRAUT-BARALON, H. EGBERNIK, T. FRYMUS, T. GRUFFYDD-JONES, K. HARTMANN, M. J. HOSIE, A. LLORET, F. MARSILIO, M. G. PENNISI, A. D. RADFORD, E. THIRY, U. TRUYEN, M. C. HORZINEK (2009): Feline leukaemia. ABCD guidelines on prevention and management. J. Feline Med. Surg. 11, 565574.

MAGI, M., M. C. PRATI, B. SEBASTIANI, P. BANDECCHI, V. GUBERTI (2002): Feline heartworm disease: a study on antibody seroprevalence in Tuscany. Vet. Rec. 150, 415-416.

MELI, M. L., V. CATTORI, F. MARTINEZ, G. LOPEZ, A. VARGAS, M. A. SIMON, I. ZORRILLA, A. MUNOZ, F. PALOMARES, J. V. LOPEZ-BAO, J. PASTOR, R. TANDON, B. WILLI, R. HOFMANN-LEHMANN, H. LUTZ (2009): Feline leukemia virus and other pathogens as important threats to the survival of the critically endangered Iberian lynx (Lynx pardinus). PLoS One. 4, e4744.

MOORE, G. E., M. P. WARD, J. DHARIWAL, C. C. WU, N. W. GLICKMAN, H. B. LEWIS, L. T. GLICKMAN (2004): Use of a primary care veterinary medical database of surveillance of syndromes and diseases in dogs and cats. J. Vet. Intern. Med. 18, 386.

MUIRDEN,A. (2002): Prevalence of feline leukemia virus and antibodies of feline immunodeficiency virus and feline coronavirus in stray cats sent to an RSPCA hospital. Vet. Rec. 150, 621-625.

O'CONNOR, T. P., Q. J. TONELLI, J. M. SCARLETT (1991): Report of the National FeLV/FIV Awareness Project. J. Am. Vet. Med. Assoc. 199, 1348-1353. 
M. Perharić et al.: The epidemiology features of retroviral infections in domestic cats from the Zagreb urban area

PACCITTI, A. M., O. JARRETT, D. HAY (1986): Transmission of feline leukaemia virus in the milk of a non-viraemic cat. Vet. Rec. 118, 381-384.

PARK, H. S., M. KYAW-TANNER, J. THOMAS, W. F. ROBINSON (1995): Feline immunodeficiency virus replicates in salivary gland ductular epithelium during the initial phase of infection. Vet. Microbiol. 46, 257-267.

PEDERSEN, N. C. (1993): The feline immunodeficiency virus. In: The Retroviridae, (Levy, J. A., Ed.). Plenum Press. New York. pp. 181-228.

PEDERSEN, N. C., E. W. HO, M. L. BROWN, J. YAMAMOTO (1987): Isolation of a T-lymphotropic virus from domestic cats with an immunodeficiency-like syndrome. Science. 235, 790-793.

PENNISI, M. G., S. BO (1994): Indagine epidemiologica nazionale FELV/FIV. Veterinaria 8, 9-15. PERI, E. V., W. PONTI, P. DALLARA, M. ROCCHI, A. ZECCONI, L. BONIZZI (1994): Seroepidemiological and clinical survey of feline immunodeficiency virus infection in northern Italy. Vet. Immunol. Immunopathol. 40, 285-297.

POTKONJAK, A., V. VRAČAR, I. STANČIĆ, LJ. SPASOJEVIĆ KOSIĆ, D. BACIĆ, M. CINCOVIĆ, B. TOHOLJ, O. STEVANČEVIĆ, Z. RISTIĆ (2014): Occurrence of Bartonella henselae, FeLV and FIV infection in 60 stray cats from Serbia. Acta Vetrinaria 64, 378-385.

RICHARDS, J. R., T. H. ELSTON, R. B. FORD, R. M. GASKELL, K. HARTMANN, K. F. HURLEY, M. R. LAPPIN, J. K. LEVY, I. RODAN, M. SCHERK, R. D. SCHULTZ, A. H. SPARKES (2006): The 2006 American Association of Feline Practitioners Feline Vaccine Advisory Panel report. J. Am. Vet. Med. Assoc. 229, 1405-1441.

ROGERS, A. B., E. A. HOOVER (1998): Maternal-fetal feline immunodeficiency virus transmission: timing and tissue tropisms. J. Infect. Dis. 178, 960-967.

STUTZER, B., K. SIMON, H. LUTZ, M. MAJZOUB, W. HERMANNS, J. HIRSCHBERGER, C. SAUTER-LOUIS, K. HARTMANN (2011): Incidence of persistent viraemia and latent feline leukaemia virus infection in cats with lymphoma. J. Feline Med. Surg. 13, 81-87.

SYKES, J. E. (2014): Feline immunodeficiency virus infection. In: Canine and Feline Infectious Diseases. (Sykes, J. E., Ed.), Elsevier, Saunders: St. Louis, Missouri 63043, USA. pp. 209-223.

TOZON, N., A. NEMEC SVETE, M. ZEMLJIČ, M. ZAKOŠEK, D. BARLIČ-MAGANJA (2008): High prevalence of feline immunodeficiency virus (FIV) and feline leukemia virus (FeLV) in Slovenia. Acta Veterinaria 58, 191-201.

TROYER, J. L., J. PECON-SLATTERY, M. E. ROELKE, W. JOHNSON, S. VANDEWOUDE, N. VAZQUEZ-SALAT, M. BROWN, L. FRANK, R. WOODROFFE, C. WINTERBACH, H. WINTERBACH, G. HEMSON, M. BUSH, K. A. ALEXANDER, E. REVILLA, S. J. O'BRIEN (2005): Seroprevalence and genomic divergence of circulating strains of feline immunodeficiency virus among Felidae and Hyaenidae species. J. Virol. 79, 8282-8294.

VOBIS, M., J. D'HAESE, H. MEHLHORN, N. MENCKE (2003): Evidence of horizontal transmission of feline leukemia virus by the cat flea (Ctenocephalides felis). Parasitol. Res. 91, 467-470.

Vet. arhiv 88 (3), 345-354, 2018 
M. Perharić et al.: The epidemiology features of retroviral infections in domestic cats from the Zagreb urban area

YAMAMOTO, J. K., H. HANSEN, E. W. HO, T. Y. MORISHITA, T. OKUDA, T. R. SAWA, R. M. NAKAMURA, N. C. PEDERSEN (1989): Epidemiologic and clinical aspects of feline immunodeficiency virus infection in cats from the continental United States and Canada and possible mode of transmission. J. Am. Vet. Med. Assoc. 194, 4213-4220.

Received: 6 April 2017

Accepted: 29 November 2017

PERHARIĆ, M., V. STAREŠINA, N. TURK, LJ. BARBIĆ, Z. ŠTRITOF, S. HAĐINA, J. HABUS̆, V. STEVANOVIĆ, K. MARTINKOVIĆ, V. MOJČEC PERKO, Z. MILAS: Epizootiološke značajke retrovirusnih infekcija mačaka na području grada Zagreba. Vet. arhiv 88, 345-354, 2018.

\section{SAŽETAK}

Infekcije virusom mačje imunodeficijencije i virusom mačje leukemije pripadaju među najčešće zarazne bolesti mačaka i znatno utječu na njihovo zdravlje. Oba virusa pripadaju porodici Retroviridae. Kao i ostali virusi iz iste porodice, uzrokuju perzistentnu infekciju ugradnjom provirusne DNK u genom domaćina. Podaci o proširenosti obiju infekcija nužni su za utvrđivanje čimbenika rizika zaraze, mjera prevencije te dijagnostičkih metoda i postupaka sa zaraženom životinjom. Za potrebe ovog istraživanja pretražena su ukupno 324 uzorka pune krvi mačaka komercijalno dostupnim dijagnostičkim testovima. Pretraživane mačke podijeljene su u dvije skupine, slobodnoživuće mačke i bolesne mačke koje imaju vlasnika. Od ukupnog broja pretraženih mačaka infekciju mačjim virusom imunodeficijencije dokazali smo u 18.51 \% mačaka, dok je infekcija virusom mačje leukemije dokazana u 14,50 \% pretraženih životinja. Proširenost infekcije mačjim virusom imunodeficijencije potvrđena je u 13,13 \% mačaka unutar skupine slobodnoživućih mačaka, dok je 20,88 \% bolesnih mačaka koje imaju vlasnika bilo pozitivno na istu zaraznu bolest. S druge strane, $6,06 \%$ slobodnoživućih mačaka te $18,22 \%$ bolesnih mačaka koje imaju vlasnike bilo je zaraženo virusom mačje leukemije. Istraživanje potvrđuje statistički značajnu proširenost virusa mačje imunodeficijencije u muških jedinki posebno onih nekastriranih. Muške jedinke također imaju statistički veću mogućnost zaraze obama retrovirusima. Provedeno istraživanje dokazuje visoku proširenost retrovirusnih infeckcija među mačkama na području grada Zagreba. Utvrđeni čimbenici rizika zaraze virusom imunodeficijencije uključuju muški spol, nekastrirane muške jedinke te slododno držanje mačaka. Ti čimbenici rizika nisu dokazani za infekciju mačjim virusom leukemije. Mjere sprečavanja širenja obiju retrovirusnih bolesti uključuju testiranje mačaka, izdvajanje i izolaciju zaraženih, kastraciju muških mačaka te imunoprofilaksu izloženih jedinki.

Ključne riječi: virus mačje imunodeficijencije; virus mačje leukemije; proširenost; čimbenici rizika; prevencija; Hrvatska 